\title{
STUDIES IN PROTEIN HYDROLYSIS.
}

Br F. W. FOREMAN; B.A., F.I.C.

School of Agriculture, Cambridge.

Preliminary.

IN the following pages the author gives a preliminary account of his attempts to improve the methods commonly in use for the separation of the products of the hydrolysis of proteins.

On surveying these methods, improvements seemed to be possible in the process of esterification. As at present practised the acid liquid resulting from the hydrolysis is first evaporated in vacuo to a syrup. Then alcohol is added and the liquid saturated with dry hydrochloric acid gas. This fails to produce complete esterification on account of the comparatively large amount of water left in the syrup.

The partially esterified acid liquid is again evaporated in vacuo, again diluted with alcohol, and again saturated with hydrochloric acid gas, and this process is repeated twice more.

This tedious process is intended to remove most of the water present in the original syrup and that produced by esterification, but that it fails to do so is evident both from the fact that after separating the esters by Levene's improved method, several repetitions of the whole esterification process are necessary, and from the unsatisfactory yield of amino-acids which may be obtained when all these repetitions have been studiously carried out.

The first attempt to devise an improved method consisted in converting all the amino-acids into lead salts, which after completely drying were digested with excess of diethyl sulphate.

Lead sulphate separated, and esterification took place, but it was found impossible to separate the esters on account of the decomposition of some of the diethyl sulphate into sulphuric acid, which decomposed the esters on distillation.

In the course of these experiments, it was found that the whole of the esters of the various products of hydrolysis, except a small quantity 
of diketo-piperazines, were soluble in chloroform, whilst ether dissolved only the esters of the mono-amino acids.

Further experiments were made using dry lead or copper salts with ethyl sulphate, methyl sulphate, ethyl bromide and ethyl iodide, but whilst esterification usually occurred, it was not found possible to devise a practicable method of separating the esters.

During the course of the above experiments, some experience was gained in converting the products of hydrolysis into dry metallic salts, and it seemed possible that one or other of these salts might be utilized for direct esterification with alcohol and dry hydrochloric gas. It was thought that a dry salt might be esterified much more completely than the syrup formerly used which necessarily contains a considerable quantity of water.

The liquid resulting from the bydrolysis of casein by sulphuric acid in the usual way was freed from sulphuric acid by baryta. The barium sulphate was filtered off and carried with it the humin substances always formed in hydrolysis. To the clear light brown liquid excess of litharge or freshly precipitated copper hydroxide was added, and the mixture heated for some time by a current of steam until acidity disappeared. The excess of metallic oxide was filtered off, the liquid evaporated to dryness, and the residue completely dried and powdered.

When hydrolysis had been carried out by means of hydrochloric acid, the acid was removed as far as possible by evaporation on the water-bath and the resulting syrup was then subjected to a current of steam to remove still more of the acid. The liquid was then considerably diluted, heated as before with steam, and precipitated lead hydroxide added until it no longer appeared to dissolve. The humin substances separated as a dark-brown sediment containing much lead, and only a very small amount of nitrogen. When this was removed a light yellow liquid was obtained from which lead salts were obtained as before by means of litharge.

By the above method the copper salts were readily obtained in a dry condition. The final stages in the evaporation and drying of the lead salts are, however, apt to be troublesome.

The following method of esterification has been found to work satisfactorily with both lead and copper salts.

The dry salt was suspended in three times its weight of absolute alcohol, and saturated with dry hydrochloric acid gas at $0^{\circ} \mathrm{C}$. After standing over night at $0^{\circ} \mathrm{C}$., most of the hydrochloric acid was removed 
by a current of dry air. The liquid was then nearly neutralised with a saturated solution of dry ammonia gas in absolute alcohol, the temperature being kept near $0^{\circ} \mathrm{C}$ : all the time. It is important that the liquid should remain slightly acid so that the ester-hydrochlorides may not be decomposed. The ammonium chloride which had separated was filtered off, and the alcohol distilled off-at low pressure below $40^{\circ} \mathrm{C}$. Nearly the whole of the esterification water was shown to be present in the distillate by means of the hydrometer. The remaining syrupy ester-hydrochlorides were dissolved in dry chloroform, in which they are readily soluble, leaving ammonium chloride undissolved.

The chloroform solution was then shaken with a small quantity of baryta until the latter became granular. This served both to remove the last traces of water and to set free the esters from their hydrochlorides: The solid residue of baryta, etc. was filtered off; and the chloroform removed as completely as possible from the esters by distillation at low pressure below $40^{\circ} \mathrm{C}$. The mono-amino esters were then extracted from the residue by dry ether, in which practically everything rẹadily and completely dissolved, showing that the diamino substances had been retained in the baryta residue.

The filtered ethereal solution was freed from ether and distilled at $15 \mathrm{~mm}$. in a slow current of dry carbon-dioxide gas, the distillation being discontinued as soon as the temperature of the oil-bath in which the distillation flask was heated reached $130^{\circ} \mathrm{C}$. By this means decomposition of the esters during the distillation is avoided and the rough isolations of the amino acids described below show that a very good fractionation occurs.

In one experiment from about 300 grams of casein containing $49.6 \mathrm{gm}$. nitrogen, the residue of esters ready for distillation weighed 241 grams, and on distillation yielded the following ressults:

\begin{tabular}{|c|c|c|c|c|}
\hline Fraction & Temp. of Bath & $\begin{array}{l}\text { Temp. of } \\
\text { Vapour }\end{array}$ & Pressure & $\begin{array}{l}\text { Weight of } \\
\text { fraction }\end{array}$ \\
\hline $\begin{array}{c}\mathbf{1} \\
\mathbf{2} \\
\mathbf{3} \\
\text { Residue in flask } \\
\end{array}$ & $\begin{array}{r}90^{\circ} \mathrm{C} . \\
90^{\circ}-112^{\circ} \mathrm{C} . \\
112^{\circ}-130^{\circ} \mathrm{C} . \\
- \\
\end{array}$ & $\begin{array}{l}45^{\circ}-50^{\circ} \mathrm{C} \\
50^{\circ}-80^{\circ} \mathrm{C} \\
80^{\circ}-86^{\circ} \mathrm{C} \\
-\end{array}$ & $\begin{array}{l}25 \mathrm{~mm} . \\
15 \mathrm{~mm} . \\
15 \mathrm{~mm} . \\
-\end{array}$ & $\begin{array}{l}5.04 \mathrm{gms} . \\
62.51 \mathrm{gms} . \\
11.05 \mathrm{gms} . \\
94.6 \mathrm{gms} .\end{array}$ \\
\hline Total ...... & $\perp$ & - & - & $173.2 \mathrm{gms}$ \\
\hline
\end{tabular}

Fraction 1 was not further examined. From fraction 2, 10.51 gms. 
of pure leucine were obtained, and 40.7 gms. of white crystalline acids, presumably the usual mixture of leucine, valine, and proline.

From fraction 3, 1.3 gms. of phenyl-alanine hydrochloride were obtained in the usual way, the remainder resembling the mixed acids of fraction 2. The residue in the flask gave 9 gms. phenyl-alanine hydrochloride recrystallised from hot strong hydrochloric acid, $3 \mathrm{gms}$. of aspartic acid which was separated as barium aspartate, and $24 \cdot 4 \mathrm{gms}$. of glutaminic acid hydrochloride has already been separated. The experiment described has been advanced to this stage in under three weeks' work.

The author claims that by using dry salts for the esterification in the place of the watery syrup used heretofore, a very great saving of time and trouble is effected in the early stages of the process, and that a very satisfactory esterification is obtained, as the presence of much alcohol prevents the reverse effect of the small amount of water formed. The complete removal of water from a syrup is prevented by the presence of much free hydrochloric acid, and the removal of the esterification water is therefore more efficiently secured when, as in the author's process, an alcoholic solution containing the ester-hydrochlorides alone is evaporated.

It is further claimed that owing to the solubility of the ester-hydrochlorides in chloroform and the freedom of their solution from bydrochloric acid, the anhydrous baryta in small quautity and without the addition of water efficiently liberates the esters from their bydrochlorides.

The yields are as good as those obtained by the older methods. The author is pursuing the investigation and is already conscious of several important details in which improvements can be effected.

CAMBRIDGE : PRINTED BY JOHN GLAT, M.A. AT THE UNIVERSITY PRESB. 